\title{
MORPHOMETRIC ANALYSIS OF VANILLA SEEDS (ORCHIDACEAE) BY MICROSCOPIC TECHNIQUES
}

\author{
Yasmín A. Alomía ${ }^{1,2,5}$, Efrén Muñoz ${ }^{1}$, Aleyda M. Acosta-Rangel ${ }^{3}$ \\ \& J. TUPAC OTERO ${ }^{1,2,4}$
}

${ }^{1}$ Departamento de Ciencias Biológicas, Universidad Nacional de Colombia Sede Palmira

Calle $32 \mathrm{~N}^{\circ}$ 12-00, Palmira - Valle del Cauca - Colombia

${ }^{2}$ Grupo de Investigación en Orquídeas, Ecología y Sistemática Vegetal

${ }^{3}$ Departamento de Biología, Universidad del Valle, Calle 13 № 100-00, Cali - Valle del Cauca - Colombia

${ }^{4}$ Instituto de Ciencias Ambientales IDEA, Universidad Nacional de Colombia Sede Palmira.

${ }^{5}$ Corresponding author current address: Departamento de Ciencias Biológicas, Universidad de los Andes, Carrera $1 \mathrm{~N}^{\circ} 18^{\mathrm{a}}$-10, Bogotá D.C. Colombia. ya.alomia10@uniandes.edu.co

\begin{abstract}
Seed morphometric characters of four Colombian Vanilla species (Vanilla odorata, Vanilla calyculata, Vanilla oroana and Vanilla rivasii) were compared by using both light and electron microscopy. Seeds collected from mature fruits were studied by optical microscopy to characterize coat color, length and width of seeds in Vanilla species. Scanning electron microscopy (SEM) was used to characterize the seed surface and cell shape in these species. There were significant differences in length, width and length/width ratio. Vanilla oronana had the largest seeds ( $431 \pm 17 \mu \mathrm{m}$ long and $312 \pm 27 \mu \mathrm{m}$ wide) and differed from the other species by its dark brown seed coat and the presence of protrusions. Vanilla odorata was the species with smallest seeds $(310 \pm 15 \mu \mathrm{m}$ long and $222 \pm 18 \mu \mathrm{m}$ wide) and light brown seed coat. Seeds of all studied species had smooth coat surfaces and were of oval to ellipsoid in shape. The characters evaluated in this work could serve as taxonomic diagnostic markers in Vanilla and these could explain important aspects of the seed biology of this genus.
\end{abstract}

RESUMEN. Se caracterizó y se comparó la morfometría de las semillas de cuatro especies de vainillas colombianas (Vanilla odorata, Vanilla calyculata, Vanilla oroana y Vanilla rivasii). Las semillas colectadas a partir de frutos maduros fueron estudiadas por microscopía óptica para caracterizar el color, la longitud y el ancho de las semillas. Además, por medio de microscopía electrónica de barrido (MEB) se identificaron las características de la superficie de la testa. Existieron diferencias significativas en la longitud, el ancho y en la relación longitud/ ancho entre las especies. Vanilla oronana tuvo las semillas más grandes $(431 \pm 17 \mu \mathrm{m}$ de largo y $312 \pm 27 \mu \mathrm{m}$ de ancho) y difirió de las otras especies por presentar la coloración parda en tono más oscuro y por la presencia de protuberancias en la testa. Vanilla odorata fue la especie con semillas más pequeñas ( $310 \pm 15 \mu \mathrm{m}$ de longitud y $222 \pm 18 \mu \mathrm{m}$ de ancho) de color pardo claro. En general, las semillas presentaron la testa lisa y una forma elipsoide. Los caracteres evaluados en este trabajo podrían servir como marcadores taxonómicos en Vanilla y podrían explicar aspectos importantes de la biología de las semillas de este género.

KEY WORDS: Colombia, morphology, traits, orchids, Vanilla, SEM

Introduction. Most orchid seeds are smaller than $2.0 \mathrm{~mm}$ in length with small embryos and have no endosperm (Baskin \& Baskin 1998). Orchid seed length varies from 0.05 to $6.0 \mathrm{~mm}$ and there is a broad variation in the seed coat reticulation patterns, shape, size and color (Arditti \& Ghani 2000). In many species of Orchidaceae, seeds have hyaline seed-coat with visible embryos at the dissection microscope resolution without staining. Nevertheless, some genera such as Apostasia, Cyrtosia, Epistephium, Galeola, Neuwiedia, Palmorchis, Selenipedium and Vanilla have sclerotized seed coat which does not allow embryo visualization (Molvray \& Kores 1995).

Several studies has been performed on the 
TABLE 1. Source localities of Vanilla spp. seeds.

\begin{tabular}{l|l|l|c|l}
\hline Species & Locality & Life Zone* & $\begin{array}{c}\text { Elevation } \\
\text { m.a.s.I }\end{array}$ & Department \\
\hline Vanilla oroana & El Charco & Tropical wet forest & 2 & Nariño \\
\hline Vanilla rivasii & Buenaventura & Tropical wet forest & 7 & Valle del Cauca \\
\hline Vanilla calyculata & Atuncela & Tropical dry forest & 800 & Valle del Cauca \\
\hline Vanilla odorata & Ríofrío & Tropical dry forest & 1122 & Valle del Cauca \\
\hline
\end{tabular}

${ }^{*}$ According to the classification by Holdridge (1947)

morphology of native Californian orchids including Goodyera, Piperia, Platanthera and Spiranthes species (Healey, Michaud \& Arditti, 1980), Paphiopedilum and Cypripedium (Arditti et al. 1979), and Calypso, Cephalanthera, Corallorhiza and Epipactis (Arditti, Michaud \& Healey, 1980). These studies suggest that variations in size seed, shape, color and patterns of the seed coat cells have served as taxonomic and/or phylogenetic markers on seeds of native California orchids and related species (Barthlott 1976, Arditti et al. 1979, Arditti et al. 1980, Healey et al. 1980).

Additionally, seed morphology may affect important biological and ecological aspects such as seed dispersion mechanisms. Most orchid seeds have traits that favor long distance wind dispersal due to their small size, shape and large air space (Arditti \& Ghani 2000). On the other hand, the genera with lignified seed coats have contrasting dispersal mechanisms associated with endozoochory. For example, avian seed dispersal was reported in a mycoheterotrophic orchid Cyrtosia septentrionalis (Rchb.f.) Garay (Nakamura \& Hamada 1978, Suetsugu et al. 2015). Additionally, it have been suggested that seeds of Vanilla planifolia Andrews are dispersed by birds (Arditti \& Ghani 2000). Also, Schlüter, Soto-Arenas \& Harris (2007) suggested that Vanilla fruits show a typical bat dispersal syndrome, being darkly colored, pendulous, and strongly scented. In all these cases, the lignified seed coat probably protects the seeds as they pass through the digestive tracts of dispersal animals.

Vanilla Mill is a genus with nearly 110 species with pantropical distribution (Purseglove et al. 1981). Vanilla extract is an important fragrant and flavor natural product, obtained from the curated fruit of the hemiepiphyte tropical orchid Vanilla planifolia and produced mainly in Madagascar and Indonesia. In Colombia, Vanilla species are distributed below
$2000 \mathrm{~m}$ in all natural regions (Caribbean, Andean, Pacific, West plains and Amazon; Ordoñez-Osorio et al. 2011). Soto Arenas \& Dressler (2010) reported 11 species; but lately, Molineros-Hurtado, González, Flanagan and Otero (2014) described a new species from the Pacific coast. More recently, the Colombian Catalog of Plants and Lichens reported 15 Vanilla species (Bernal et al. 2015).

Despite the growing interest about Vanilla cultivation, little is known about their ecology, and the seed morphometric studies of Vanilla species are scarce (Table 1). Fruit and seed trades of four Vanilla species from Mexico using light microscopy were reported showing morphological variation among species and even clones (Reyes-López et al. 2014). One species ( $V$. planifolia) was studied using scanning electron microscopy (Barthlott et al. 2014). Developing seed morphometric studies of Vanilla species could be useful for dispersal studies, helping in the seed identification on fecal samples of the disperser potentials.

The potential use of seed morphology to support taxonomic studies has not been taken into account in the taxonomic treatment of Vanilla species. A recent revision of Vanilla for Central America includes 15 species, but only two species have information about their seeds: $V$. martinezii Soto-Arenas, and $V$. trigonocarpa Hoehne (Soto-Arenas \& Dressler, 2010). The aim of this study was to characterize the seed morphometry of four Colombian Vanilla species, using light microscopy and scanning electron microscopy.

Materials and Methods. Seeds from mature fruits of four Colombian Vanilla species: Vanilla calyculata Schltr; V. odorata C.Presl; V. oroana Dodson; and $V$. rivasii Molineros et al. were collected from various locations of Colombia (Table 1). Seeds at the 
TABLE 2. Length and width average of Vanilla seeds.

\begin{tabular}{l|c|c|c}
\hline Species & Mean Lenght $(\mu \mathrm{m})^{*}$ & Mean width $(\mu \mathrm{m})^{*}$ & Lenght/width Ratio $^{*}$ \\
\hline V. oroana & $431.24 \pm 17.24 \mathrm{a}$ & $312.12 \pm 27.30 \mathrm{a}$ & $1.39 \pm 0.12 \mathrm{~b}$ \\
\hline V. calyculata & $393.41 \pm 18.30 \mathrm{~b}$ & $320.82 \pm 14.78 \mathrm{a}$ & $1.23 \pm 0.06 \mathrm{a}$ \\
\hline V. rivasii & $339.56 \pm 15.97 \mathrm{c}$ & $228.21 \pm 14.26 \mathrm{~b}$ & $1.49 \pm 0.10 \mathrm{c}$ \\
\hline V. odorata & $310.74 \pm 15.62 \mathrm{~d}$ & $222.10 \pm 17.92 \mathrm{~b}$ & $1.41 \pm 0.12 \mathrm{~b}$ \\
\hline
\end{tabular}

${ }^{*}$ The mean value \pm standard deviation $( \pm S D)$ is reported. Different letters indicate significant differences $(P \leq 0.05)$ among species after a Tukey test.

TABLE 3. Reported seed size in others studies for Vanilla spp.

\begin{tabular}{l|c|c|l}
\hline Specie & Length $(\boldsymbol{\mu m})$ & Width $(\boldsymbol{\mu m})$ & Reference \\
\hline V. inodora & 292.02 & 151.90 & Reyes-López et al., 2014 \\
\hline V. pompona & 286.20 & 183.47 & Reyes-López et al., 2014 \\
\hline V. insignis & 323.51 & 267.88 & Reyes-López et al., 2014 \\
\hline V. planifolia* & 286.08 & 232.17 & Reyes-López et al., 2014 \\
\hline V. planifolia & 250 & 220 & Bouriquet, 1947 \\
\hline V. trigonocarpa & 600 & - & Soto-Arenas \& Dressler, 2010 \\
\hline V. planifolia & 500 & - & Barthlott et al., 2014 \\
\hline
\end{tabular}

${ }^{\star}$ Average for 10 accessions

midsection of the fruit of at least two fruits per species were extracted and washed following Knudson protocol (Knudson 1950). Seeds were deposited in $5 \mathrm{~mL}$ Eppendorf tubes and dehydrated in $3 \mathrm{~mL}$ of absolute ethanol and shacked with ultrasound twice for five minutes. For optic microscopy, seeds were mounted over slides with gelatine-glycerine and sealed with paraffin. Slides were observed in an optical microscope (NIKON ECLIPSE NI-U90) at the Image laboratory at Universidad del Valle, Cali, Colombia. Seed length and width measurements, were obtained using a microscope imaging software (NIS-Elements $\mathrm{Br}$ ) to 40 seeds per species. Additionally, a dissection microscopy (SEM; NIKON SMZ 800) was used for describing the seed color. For detailed observation of seed coat traits, cleaned seeds were dried at room temperature for 24 hours, then seeds were fixed on carbon tape and covered with gold-palladium for 80 seconds. Samples were observed using a SEM (HITACHI S4800) at the Image laboratory at Universidad de Valencia, Valencia, Spain. Statistical analysis (Descriptive statistics, ANOVA and Tukey test) of length, width and length/width ratio were performed using Statistica 7.0 and R 3.1.1 software. Comparison among means were done considering statistically significant differences if $\mathrm{p}<0.05$.
Results. There were significant differences in seed length $\left(\mathrm{F}_{3,156}=410.36, \mathrm{p}<0.005\right)$, width $\left(\mathrm{F}_{3,156}=\right.$ 297.84, $\mathrm{p}<0.005)$ and length/width ratio $\left(\mathrm{F}_{3,156}=48.35\right.$, $\mathrm{p}<0.005)$ among species. For seed length, the tukey test (Table 2) indicated that all species were different. Vanilla oroana had the largest seeds $(431 \pm 17 \mu \mathrm{m} x$ $312 \pm 27 \mu \mathrm{m})$, while $V$. odorata had the smaller ones $(310 \pm 15 \mu \mathrm{m} \times 222 \pm 18 \mu \mathrm{m})$. For seed width, there were two groups significantly different from each other; the first form by $V$. oroana $(312.12 \pm 27.30)$ and $V$. calyculata $(320.82 \pm 14.78)$ and the second included $V$. rivasii $(228.21 \pm 14.26)$ and $V$. odorata $(222.10$ \pm 17.92). The length/width ratio of $V$. calyculata $(1.23 \pm 0.06)$ was close to one as a consequence of the circular shape pattern, while in $V$. rivasii that had ellipsoid seeds, its ratio was higher than one (1.49 \pm 0.10$)$-On the other hand, $V$. oroana $(1.39 \pm 0.12)$ y $V$. odorata $(1.41 \pm 0.12)$, which had an intermediate shape between spherical and ellipsoid, don't showed differences (Table 2).

Microscopic images of $V$. calyculata (Fig. 1), V. oroana (Fig. 2), V. odorata (Fig. 3) and V. rivasii (Fig. 4) are presented. Vanilla calyculata, V. odorata and $V$. rivasii had an oval-planar corpus (Figs. 1, 3 y 4, respect.), while $V$. oroana, had an oval-globular corpus with protuberances that gave an irregular appearance 




FIGURE 1. Seeds of Vanilla calyculata a-b. Optic microscopy images. c-f. Scanning electron microscopy (SEM) images.



Figure 3. Seeds of Vanilla odorata. a-b. Optic microscopy images. c-f. Scanning electron microscopy (SEM) images.
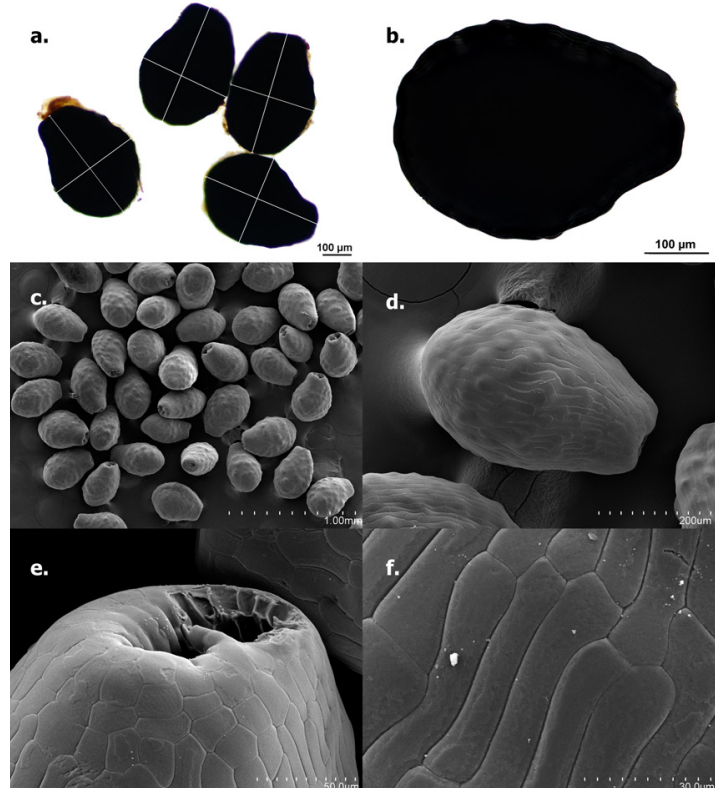

Figure 2. Seeds of Vanilla oroana. a-b. Optic microscopy images. c-f. Scanning electron microscopy (SEM) images.


FIgURE 4. Seeds of Vanilla rivasii. a-b. Optic microscopy images. c $-\mathrm{f}$. Scanning electron microscopy (SEM) images. 
(Fig. 2c-d). The cells of the seed coats of the four studied species were smooth, with a longitudinal aperture and without reticulation patterns. In all studied species, the cells around the micropile are square or polygonal, contrasting with the rectangular shape of the cells in the central part of the seed (Figs. 1d, 2d, 3d, 4d). Relative to the seed color, all species had brown seeds; however, a tonality variation was observed. The darkest seeds were those of $V$. oroana and the lightest ones were from $V$. odorata (Figs. 1a-b, 2a-b, 3a-b, 4a-b).

Discussion. We found a seed morphological variation among Vanilla studied species that is consistent with other comparative studies (Table 3 ). The seeds of the Colombian Vanilla species were within the known seed size range. The smallest reported Vanilla seeds are those from $V$. planifolia $(250 \pm 80 \mu \mathrm{m} \times 220 \pm 60$ $\mu \mathrm{m}$; Bouriquet 1947). However, Barthlott et al. (2014) reported seed length of $500 \mu \mathrm{m}$ for $V$. planifolia. Thus, it is necessary to conduct rigorous studies to evaluate intraspecific variation. Other studies with mexican vanillas have reported that Vanilla species with the biggest seeds was $V$. insignis Ames (323.51 $\mu \mathrm{m} \times 267.99 \mu \mathrm{m})$, while $V$. inodora Schiede had the smallest seeds $292.02 \mu \mathrm{m}$ x $151.90 \mu \mathrm{m}$ (Reyes-López et al. 2014; Table 3). Taking into account of color of the seeds, Vanilla species have been reported as dark-brown (Knudson 1950; Hernández-Hernández 2011). In our study we found that there is variation in the tonality from light to dark -brown, close to black among species. Given the kwon variation in Vanilla seed size, this parameters show the potential for Vanilla taxonomy. Nevertheless, it is necessary more studies on Vanilla seeds to cover the nearly 110 described species.

Vanilla seed morphology could be useful in dispersal mechanisms studies. The Vanilla dispersion mechanisms are not well known; however, some studies have suggested a possible dispersion through endozoochory, mainly by birds (Nakamura \& Hamada 1978, Barthlott et al. 2014). In addition, it has been suggested that euglossinae bees disperse Vanilla seeds due to the collection of vanillin by the male of this species for female attraction (Soto-Arenas \& Dressler 2010). Identification of Vanilla seeds from animal feces may shed light on this old and interesting question.
After dispersion, seeds require developing into the seedling stage, and morphological trades recognized in seeds may be related with the germination process. The thickness of the seed coat could be involved in dormancy process and development of seed banks (Baskin \& Baskin 1998). Alternatively, it could help the seeds to survive passing through an animal's digestive system during seed dispersion as in other seeds with lignified seed coat (Traveset et al. 2007, Suetsugu et al. 2015). As with other orchids, Vanilla seeds require mycorrhizal fungi for germination under field conditions (Porras-Alfaro \& Bayman 2007). In Colombia, Ceratobasidium and Tulasnella fungi were reported as mycorrhizal in Vanilla spp. (MosqueraEspinosa et al. 2010, Alomía 2014).

Regarding the techniques used in this study, combining the optical microscopy with the use of permanent slides allowed to observe the coat color and take easily morphometric measurements, all at low cost. On the other hand, images in SEM at high resolution allowed the observation of the external structures of seeds, highlighting the smooth ornamentation in all studied species. Therefore, both approaches are complementary for a complete characterization of the seeds. Given the economic importance of Vanilla, this study reports new data about morphometric characteristics that may be useful for future taxonomic and ecological studies. Additionally, the techniques here reported could be applied for determining the species of Vanilla used on commercial vanilla products.

AcKNOwLedGements. Special thanks to Rachel Eugenia Galián and Julia Perez of the Universidad de Valencia (Spain) for their assistance with taking SEM images. Juan Felipe Ortega from Laboratory Imaging Universidad del Valle (Colombia) for facilitating the optical microscope and take the images, Yeferson Granado and Robert Tulio Gonzalez for collecting fruits used in this study, John Chater for reviewing the language and comments, Johnathan Alomía for image editing, and two anonymous reviewers for useful comments and suggestions.

\section{LiTERARURE CITED}

Alomía, Y. A. (2014). Hongos micorrízicos en Vanilla spp. (Orchidaceae) y su potencial para la germinación de semillas. Tesis de maestría, Universidad Nacional de Colombia. Palmira, Colombia. 108 p.

Arditti, J., Michaud, J. D., \& Healey, P. L. (1979). 
Morphometry of orchid seeds. I. Paphiopedilum and native California and related species of Cypripedium. American Journal of Botany, 66, 1129-1139. DOI: 10.4236/oje.2014.42005.

Arditti, J., Michaud, J. D., \& Healey, P. L. (1980). Morphometry of orchid seeds II. Native California and related species of Calypso, Cephalanthera, Corallorhiza and Epipactis. American Journal of Botany, 67, 347360. DOI: $10.2307 / 2442345$.

Arditti, J. \& Ghani, A. K. A. (2000). Tansley Review no. 110. Numerical and physical properties of orchid seeds and their biological implications. New Phytologist, 145, 367-421. DOI: 10.1046/j.1469-8137.2000.00587.x.

Barthlott, W. (1976). Morphologie der Samen von Orchideen in Hinblick auf taxonomische und functionelle Aspecte. Proc. 8th World Orchid Conf., Frankfurt, 1975: pp. 444455.

Barthlott, W., Große-Veldmann, B., \& Korotkova, N. (2014). Orchid seed diversity. Botanic Garden and Botanical Museum Berlin-Dahlem. Berlin, Germany.

Baskin, C.C. \& Baskin J. M. (1998). Seeds: Ecology, Biogeography, and Evolution of Dormancy and Germination. California, USA: Academic Press, San Diego.666p.

Bernal, R., Gradstein, S. R., \& Celis, M. (2015). Catálogo de plantas y líquenes de Colombia. Instituto de Ciencias Naturales, Universidad Nacional de Colombia, Bogotá. http://catalogoplantasdecolombia.unal.edu.co/catalogo.

Bouriquet, G. (1947). Sur la germination des graines de vanillier (Vanilla planifolia Andr.). L'agronomie tropicale, 2, 150-164.

Healey, P. L., Michaud, J. D., \& Arditti, J. (1980). Morphometry of orchid seeds. III. Native Claifornia and related species of Goodyera, Piperia, Platanthera and Spiranthes. American Journal of Botany, 67, 508-518.

Hernández-Hernández, J. (2011). Mexican Vanilla production. In: Havkin-Frenkel, D. \& F. C. Belanger eds. Handbook of Vanilla science and technology. First edition. Blackwell publishing ltd. Pp. 3-25. DOI: 10.1002/9781444329353.ch1.

Holdridge, L. R. (1947). Determination of world plant formations from simple climatic data. Science, 105, 367-368. DOI: 10.1126/science.105.2727.367.

Knudson, L. (1950). Germination of seeds of Vanilla. American Journal of Botany.37, 241-247. DOI: $10.2307 / 2437909$.

Molineros-Hurtado, F.; González Mina, R. T; Flanagan, N. S \& Otero, J. T. (2014). Vanilla rivasii (Orchidaceae), a new species from the Colombian pacific region.
Lankesteriana 13, 353-357. DOI. http://dx.doi. org/10.15517/lank.v13i3.14423.

Mosquera-Espinosa, A. T., Bayman, P. \& Otero J. T. (2010). Ceratobasidium como hongo micorrízico de orquídeas en Colombia. Acta Agronómica, 59, 316-326.

Molvray, M. \& Kores, P. J. (1995). Character analysis of the seed coat in Spiranthoideae and Orchidoideae, with special reference to the Diurideae (Orchidaceae). American Journal of Botany, 82, 1443-1454. DOI: $10.2307 / 2445872$.

Nakamura S. I. \& Hamada, M. (1978). On the seed dispersal of an achlorophyllous orchid, Galeola septentrionalis. Journal of Japanese Botany, 53, 260-263.

Ordoñez, N. F., Osorio, A. I., Calle, J.E., Díez, M. C. \& Moreno F. (2011). La vainilla en Colombia y en el mundo. In: Moreno, F. and Díez, M. C. Cultivo de Vainilla, contribuciones para el desarrollo de su cadena productiva en Colombia. Medellín, Colombia.

Porras-Alfaro, A., \& Bayman, P. (2007). Mycorrhizal fungi of Vanilla: diversity, specificity and effects on seed germination and plant growth. Mycologia , 99, 510-525. DOI: 10.3852/mycologia.99.4.510.

Purseglove, J. W., Brown, E. G., Green, C. I., \& Robbins, S. R. J. (1981). Spices. Tropical Agricultural Series, vol. 2. Longman inc., New York, pp. 644-735.

Reyes-López, D., Flores-Jiménez, Á., Huerta-Lara, M., KelsoBucio, H. A., Avendaño- Arrazate, C. H., Lobato-Ortiz, R., \& López-Olguín, J. F (2014). Variación morfométrica de fruto y semilla en cuatro especies del género Vanilla. Ecosistemas y Recursos Agropecuarios, 1, 205-218.

Soto-Arenas, M. A., \& Dressler, R. L. (2010). A revision of the Mexican and Central American species of Vanilla plumier ex miller with a characterization of their ITS region of the nuclear ribosomal DNA. Lankesteriana, 9, 285-354. DOI: http://dx.doi.org/10.15517/lank. v0i0.12065.

Schlüter, P. M., Soto-Arenas, M. A. \& Harris, S. A. (2007). Genetic Variation in Vanilla planifolia (Orchidaceae). Economic Botany, 61(4):328-336. DOI: 10.1663/0013-0001(2007)61[328:GVIVPO]2.0.CO;2

Suetsugu, K., Kawakita, A., \& Kato, M. (2015). Avian seed dispersal in a mycoheterotrophic orchid Cyrtosia septentrionalis. Nature Plants, 1(5). DOI:10.1038/ nplants.2015.52

Traveset, A., Robertson, A. W., \& Rodríguez-Pérez, J. (2007). A review on the role of endozoochory on seed germination. In Denis AJ. Ed. Seed dispersal: theory and its application in a changing world. CABI Publishing, Wallingford, UK, 78-103. 